\title{
BrO measurements over the Eastern North-Atlantic
}

\author{
M. Martin ${ }^{1, *}$, D. Pöhler ${ }^{1}$, K. Seitz ${ }^{1}$, R. Sinreich ${ }^{1, * *}$, and U. Platt ${ }^{1}$ \\ ${ }^{1}$ Institute of Environmental Physics, University of Heidelberg, Im Neuenheimer Feld 229, 69120 Heidelberg, Germany \\ * present address: ETH Institute for Atmospheric and Climate Science, Universitaetstrasse 16, 8092 Zurich, Switzerland \\ ** present address: Department of Chemistry and Biochemistry, University of Colorado at Boulder, UCB 215, Boulder, \\ CO 80309-0215, USA
}

Received: 17 December 2008 - Published in Atmos. Chem. Phys. Discuss.: 8 April 2009

Revised: 27 November 2009 - Accepted: 27 November 2009 - Published: 21 December 2009

\begin{abstract}
The aim of the work presented here was to detect $\mathrm{BrO}$ in the marine boundary layer over the Eastern North-Atlantic by Multi AXis-Differential Optical Absorption Spectroscopy (MAX-DOAS) of scattered sunlight. With this technique, information about the concentration and the vertical profile of trace gases in the atmosphere can be gained. $\mathrm{BrO}$ can be formed in the marine atmosphere by degradation of biogenic organohalogens or by oxidation of bromide in sea salt aerosol. BrO influences the chemistry in marine air in many ways, e.g. since it catalytically destroys ozone, changes the $\mathrm{NO}_{2} / \mathrm{NO}$-ratio as well as the $\mathrm{OH} / \mathrm{HO}_{2}$ ratio and oxidises DMS. However, the abundance and the significance of $\mathrm{BrO}$ in the marine atmosphere is not yet fully understood.

We report on data collected during a ship cruise, which took place along the West African Coast in February 2007, within the framework of the Surface Ocean PRocesses in the ANthropocene project (SOPRAN). Tropospheric BrO could be detected during this cruise at peak mixing ratios of (10.2 \pm 3.7$) \mathrm{ppt}$ at an assumed layer height of $1 \mathrm{~km}$ on 18 February 2007. Furthermore, it was found that the mean BrO concentrations increased when cruising close to the African Coast suggesting that at least part of the $\mathrm{BrO}$ might have originated from there.
\end{abstract}

\section{Introduction}

The halogen compound bromine oxide (BrO) plays an important role in stratospheric chemistry (where it was first detected by Molina and Rowland, 1974) as well as in the troposphere, because of its ability to destroy ozone in a catalytic reaction cycle (e.g. von Glasow and Crutzen, 2007). In the

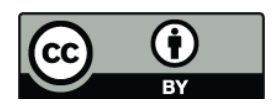

Correspondence to: M. Martin (maria.martin@env.ethz.ch) troposphere, $\mathrm{BrO}$ was first positively identified in polar regions (e.g. Tuckermann et al., 1997), where it can lead to total ozone depletion (Barrie et al., 1988; Bottenheim et al., 1990). Furthermore, $\mathrm{BrO}$ is found, although at smaller concentrations, in the marine boundary layer (MBL) in mid-latitudes (e.g. Leser et al., 2003; Saiz-Lopez et al., 2004).

Since the sources, the reactions, and the loss processes of $\mathrm{BrO}$ in the MBL are not yet completely understood, predictions of $\mathrm{BrO}$ concentrations have large uncertainties. Furthermore, investigations concerning this topic are rare, in particular over the open ocean. This work, therefore, describes $\mathrm{BrO}$ measurements in the MBL of the Eastern North-Atlantic in February 2007, which were performed to gain more insights in the $\mathrm{BrO}$ abundance in this area.

Reactive bromine is released to the MBL by different processes. First by autocatalytic liberation from sea salt aerosols, from which $\mathrm{Br}_{2}$ or $\mathrm{BrCl}$ can be released, yielding Br after photolysis (Fan and Jacob, 1992; Vogt et al., 1996).

Bromine can also be released from volatile organohalogens (like $\mathrm{CHBr}_{3}$ ), which are emitted by marine algae and accumulate in the troposphere (e.g. Quack et al., 2004). The latter source is very strong near the coast or in upwelling regions (see for example the recent measurements by Carpenter et al., 2009).

Organohalogens are also emitted by halophytes (e.g. Rhew et al., 2000), plants (e.g. mangroves in tropical regions) growing in areas with high salt concentrations like salt marshes, mangrove regions or seashores. However, their importance as source for halogens in the atmosphere is still unclear (Varner et al., 1999). The organohalogens emitted by marine algae or by halophytes can be photolysed or react with $\mathrm{OH}$, thus forming bromine radicals. Bromine atoms in the troposphere are quickly oxidised by $\mathrm{O}_{3}$ yielding $\mathrm{BrO}$.

Dust plumes are another abiotic factor that might influence the release of halogen compounds in the marine boundary layer. It is widely accepted that dust provides an important reactive surface (Usher et al., 2003) and that there might be

Published by Copernicus Publications on behalf of the European Geosciences Union. 
reactions of halogens on dust surfaces or releases of reactive halogen species from dust (e.g. Williams et al., 2007). However, the extent of its influence is not yet known. Also a liquid-phase reaction of $\mathrm{HOBr}$ (see below) with $\mathrm{BrO}$ can lead to the so-called "bromine explosion" (Platt and Lehrer, 1996; Wennberg, 1999), which derives its name from the exponentially increasing release of reactive bromine into the gas phase. This process appears to dominate in polar regions, but may also play a role elsewhere.

Reactive bromine species can have various influences on the chemistry in the boundary layer. They can destroy ozone, change the $\mathrm{NO} / \mathrm{NO}_{2}$ and the $\mathrm{OH} / \mathrm{HO}_{2}$ ratio or oxidise dimethylsulfide (DMS) (for a more detailed description see e.g. Simpson et al., 2007).

There are two ozone destroying cycles in the troposphere involving $\mathrm{Br}$. In both cycles, $\mathrm{Br}$ is oxidised by $\mathrm{O}_{3}$, which in turn - can be reduced to $\mathrm{Br}$ in two different ways: first, $\mathrm{BrO}$ reacts with $\mathrm{HO}_{2}$ to form $\mathrm{HOBr}$. Next, the hypobromous acid is photolysed and recycles back $\mathrm{Br}$ and the hydroxyl radical. This cycle typically dominates when low bromine radical levels are present, as found in the MBL. The other ozone destroying cycle is a self reaction or cross reaction of two halogen oxide molecules, but it plays only an important role at high $\mathrm{BrO}$ levels, e.g. in polar regions or over salt pans. More details can be found e.g. in von Glasow and Crutzen (2007).

Leser et al. (2003) were the first to directly detect bromine monoxide in the marine boundary layer in mid-latitudes. They found a maximum concentration of $2.4 \pm 2.1 \mathrm{ppt}$ (assuming a layer height of $1 \mathrm{~km}$ ) north of the Canary Islands at $13^{\circ} \mathrm{W}$ and $30^{\circ}$ to $37^{\circ} \mathrm{N}$. Later, Saiz-Lopez et al. (2004) measured BrO by LP-DOAS at Mace Head, on the west coast of Ireland, with a maximum daytime concentration of $6.5 \mathrm{ppt}$. Further shipborne measurements at mid-latitudes with a minimum daytime value of $3 \mathrm{ppt}$ were made by Ibrahim (personal communication, 2008). These investigations were also undertaken close to the Canary Islands. Very recent LP-DOAS $\mathrm{BrO}$ and IO measurements by Read et al. (2008) at Sao Vicente (Cape Verde Islands) also showed a nearly continuous presence of daytime $\mathrm{BrO}$ in the tropical marine boundary layer.

The $\mathrm{BrO}$ measurements presented here were made during a cruise (P348) of the German research vessel Poseidon within the framework of the Surface Ocean PRocesses in the ANthropocene (SOPRAN, for further details: www.sopran.pangaea.de) project and took place from Gran Canaria via the Cape Verde Islands and back along the West African Coast to Gran Canaria (see Fig. 2). The cruise took place from 8 February to 24 February 2007. The West African Coast is an interesting site for the investigation of $\mathrm{BrO}$, since the biological activity is very high in this region during this time of year with typical high chlorophyl concentrations and blooming plankton. This is caused by the large upwelling in this region and the strong dust impact from the Sahara Desert (e.g. Middleton and Goudie, 2001).
Furthermore, the Mauritanian coast is nearby, where halophytes occur in a significant amount. Thus, air masses coming from there might contain organohalogens emitted from these plants.

We applied the MAX-DOAS technique, which analyses scattered sunlight at different elevation angles (the angles between the viewing direction and the horizontal direction). This implies, that light reaching the telescope at a smaller elevation angle has travelled a longer path through the investigated tropospheric trace gas layer (with a given vertical extension). Thus, information about the vertical distribution of tropospheric trace gases can be obtained (Hönninger et al., 2004). During daylight hours continuous measurements were taken throughout the entire duration of the cruise. One measurement series (a set of 6 to 8 different elevation angles) took between 10 and $20 \mathrm{~min}$, depending on the light conditions. The set of elevation angles used was modified several times in order to optimize the measurements. However, the angles $6^{\circ}, 3^{\circ}, 2^{\circ}$ and $1^{\circ}$, which are most sensitive for tropospheric trace gases, were always included. Measurement interruptions occured due to malfunctions of the instrument producing discontinuity in the data series lasting from half an hour to two hours.

Also iodine oxide was measured, the precursors of which are emitted mainly by algae.

\section{The measurements}

\subsection{The instrument}

The MAX-DOAS instrument consists of three separate telescopes, that are connected via quartz fibre bundles (7 fibres per bundle) to an Acton Spectra Pro 300 Imaging Spectrometer with an Andor CCD Camera (DV 420-OE). The 2-Ddetector ( 1024 by 256 pixels) records the spectra of the three telescopes simultaneously. This is accomplished by illuminating a CCD chip with a fiber bundle from each telescope. (The radiation collected by each telescope illuminated 50 of the 256 rows of CCD-detector pixles.) For that purpose, the fiber endings are arranged in a column at the spectrometer entrance slit. The telescopes were placed on a gimbal mount, which compensates for the pitch and roll of the ship. The angles of the gimbal mount did vary in a range of $1^{\circ}$ to $2^{\circ}$ for windy days, and less for calmer days. The entire set up was mounted at the top deck. The line of sight of one telescope was in direction of the bow of the ship. In order to increase the total observed area, the two other telescopes had a slightly offset azimuth angle (about $20^{\circ}$ ) to the left or right of the centre telescope, respectively. However, this offset was too small to see any significant differences in the measured $\mathrm{BrO}$ signals. Each of the three telescopes measured the same sequence of elevation angles shifted in phase to each other. Thus, the time required to record one set of elevation angles was reduced and the total time resolution improved. 
Spectra were recorded in the ultraviolet/visible wavelength range from circa $330-460 \mathrm{~nm}$. A more detailed description of the instrument can be found in Wagner et al. (2004).

\subsection{Data analysis}

The recorded spectra were analysed for $\mathrm{BrO}$ with the Differential Optical Absorption Spectroscopy method (Platt, 1994) using the software WinDOAS (van Roozendael and Fayt, 2001). Thereby, the characteristic absorption structures of the trace gases are used for their identification in the recorded spectra. A wavelength range from $346 \mathrm{~nm}$ to $359 \mathrm{~nm}$ was chosen, where the $\mathrm{BrO}$ absorption features are still significant, while at the same time the influence of overlapping absorption structures due to ozone is minimised. Furthermore a dark current and an offset spectrum were recorded at regular intervals to account for detector dark signal and electronic offset.

During the analysis process, in addition to the trace gas literature spectra several other spectra are fitted simultaneously to the logarithm of the measured spectra using the least-squares method (Stutz and Platt, 1996). These spectra are a Fraunhofer spectrum (FRS), a Ring spectrum, a polynomial, the corresponding trace gas spectra and an additive polynomial.

The FRS accounts for the solar Fraunhofer lines as well as for diode to diode variations. It was taken with the same measurement device at an $80^{\circ}$ elevation angle, since the light path under a $90^{\circ}$ angle was blocked by a mast of the ship. The second order polynomial represents broad band structures and the constant additive polynomial was included to account for stray light in the spectrograph. The Ring spectrum (Grainger and Ring, 1962) accounts for the effect of rotational Raman scattering in the atmosphere, it was calculated from the respective FRS with DOASIS (Kraus, 2005). The trace gas reference spectra, which were considered in this wavelength range were a $\mathrm{BrO}$ spectrum by Wilmouth et al. (1999), a $\mathrm{NO}_{2}$ spectrum at $220 \mathrm{~K}$ and one at $294 \mathrm{~K}$, both by Vandaele et al. (1998), an $\mathrm{O}_{3}$ spectrum at $223 \mathrm{~K}$ and one at $273 \mathrm{~K}$, both by Bogumil et al. (2003). An example of a $\mathrm{BrO}$ fit resulting in high $\mathrm{BrO}$ column densities $\left(2.11 \times 10^{14} \mathrm{molec} / \mathrm{cm}^{2}\right)$ is shown in Fig. 1.

The data analysis yields "differential" slant column densities (DSCDs) for the fitted trace gases, where slant column densities $S$ (SCDs) are defined as the integrated concentration $c$ along the light path $L$ under the investigated elevation angle $\alpha$ and DSCDs are then: $\operatorname{DSCD}(\alpha)=S(\alpha)-S_{\text {ref }}\left(80^{\circ}\right)$, with $S_{\text {ref }}\left(80^{\circ}\right)$ being the slant column density of the chosen FRS. Two methods to determine DSCDs were applied in the here presented work, which differ in the way the FRS is selected. In the first, the spectra of the entire day are analysed using a fixed FRS taken at noon of the same day. Thus, the stratospheric trace gas columns, which change over the course of the day, show up in the results of this analysis, which are denoted dSCDs. The second method yields
$\Delta$ SCDs, which are evaluated using the FRS closest in time to the respective measurement spectra (i.e. the measurement at $\alpha=80^{\circ}$ recorded as part of either the previous or the current set of elevation angles). This method has the advantage, that the stratospheric signal can largely be neglected, since the stratospheric $\mathrm{BrO}$ column changes during a single scanning sequence are very small (except for the early morning and late evening). The $\triangle \mathrm{SCDs}$ values, therefore, essentially only reflect the tropospheric $\mathrm{BrO}$ signal.

\subsection{Radiative transfer modelling}

The dSCD values retrieved from the data analysis are dependent on the length of the light path $L$ and thus on the number of scattering events in the atmosphere. Also the elevation angle $\alpha$ influences the magnitude of the SCD. The vertical column density $V$ (VCD) in contrast is independent of the measurement specific light path and of the line of sight, and is determined to facilitate intercomparison with other measurements from different platforms and model values. It is defined as the concentration $\mathrm{c}$ integrated along the vertical height $z$. It can be transferred from $\mathrm{S}$ using the air mass factor $A$ (AMF), which is the ratio of $S$ and $V, A=\frac{S}{V}$. A takes into account the radiative transfer within the atmosphere and can be determined using radiative transfer models. Those account also for multiscattering events and the ground albedo. In the here presented work the model McArtim (Deutschmann, 2008) was applied to calculate the airmass factors. Also the layer height $h$ can be estimated using this model. The trace gas concentration $c$ can then be derived through the relation $c=V / h$.

Finally two simulation runs were performed. In the first, the known height profile of the trace gas $\mathrm{O}_{4}$ was used to estimate the aerosol profile present in the atmosphere, which is a strong influence factor to the optical properties of the atmosphere (e.g. Wagner et al., 2004). Thereby, $\mathrm{O}_{4}$ air mass factors were modelled using arbitrary a priori aerosol profiles as input. These were compared to air mass factors, which were calculated from measured $\mathrm{O}_{4} \mathrm{dSCD}$ - also gained with the DOAS method - using the known vertical column density of $\mathrm{O}_{4}$, as described in more detail in Sinreich et al. (2005). The aerosol profile was changed until a good match between the modelled and calculated AMFs was obtained. In the second simulation run, which derived the $\mathrm{BrO}$ profile, the best fitting aerosol profile was used as fixed input. Assuming a layer with constant $\mathrm{BrO}$ concentration (defined as box profile) the height of this $\mathrm{BrO}$ layer could be yielded.

The following correlation was applied comparing simulated $\mathrm{BrO}$ AMFs with measured $\mathrm{BrO}$ SCDs:

$$
\frac{\bar{S}(\alpha)-\bar{S}\left(80^{\circ}\right)}{\bar{S}(\beta)-\bar{S}\left(80^{\circ}\right)}=\frac{A(\alpha)-A\left(80^{\circ}\right)}{A(\beta)-A\left(80^{\circ}\right)}
$$

where $\bar{S}$ is the averaged dSCD for the investigated time period and $\alpha, \beta$ and $80^{\circ}$ denote the respective elevation angle. 

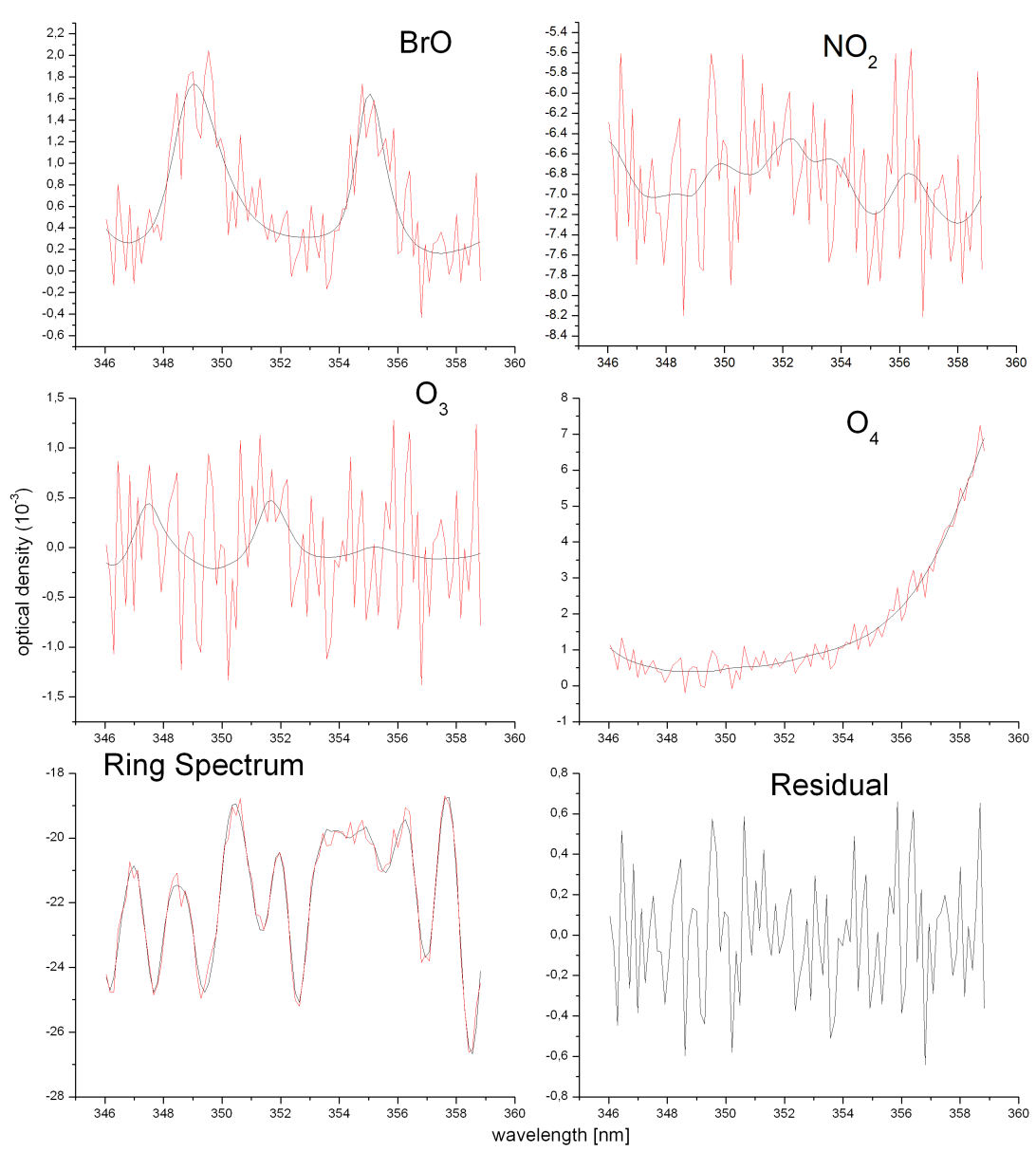

Fig. 1. An example of a WinDOAS fit for $\mathrm{BrO}$ for a spectrum with high $\mathrm{BrO}$ values at $6^{\circ}$ elevation angle. It was taken on 18 February at 14:56 UTC. (The displayed optical densities are defined as the product of the slant column density and the respective cross section.) The resulting dSCDs are: $\mathrm{dSCD}(\mathrm{BrO})=2.11 \times 10^{14} \mathrm{molec} / \mathrm{cm}^{2}, \mathrm{dSCD}\left(\mathrm{NO}_{2}\right)=-1.21 \times 10^{16} \mathrm{molec} / \mathrm{cm}^{2}, \mathrm{dSCD}\left(\mathrm{O}_{3}\right)=2.49 \times 10^{18} \mathrm{molec} / \mathrm{cm}^{2}$.

The height of the BrO layer was changed in the simulation until the simulation matched the measurement. However, the gained layer height is an effective layer height, meaning that smoother transitions as well as small inhomogeneities existing in the atmosphere are averaged out. Thus, this layer is a modelled parameter with the quality that it adjusts the modelled AMFs as good as possible to the measured dSCDs. The mean ratio between the $\mathrm{BrO}$ dSCDs and the modelled $\mathrm{BrO}$ dAMF yielded the BrO VCD.

In both simulations, the albedo over the ocean was assumed to be 0.02 , the single scattering albedo 0.95 and the asymmetry parameter 0.68 . The wavelength for the retrieval of the aerosol profile was $361 \mathrm{~nm}$, and for the $\mathrm{BrO}$ profile $349 \mathrm{~nm}$. Sensitivity calculations with an albedo of $4 \%$ and an asymmetrie parameter of 0.74 gave less than $3 \%$ lower $\mathrm{BrO}$ concentrations.

\subsection{Error estimation}

The overall errors of the given concentrations consist of different parts. First, there is a statistical error of the evaluated dSCDs, which is derrived as described in Stutz and Platt (1996). It is also given by the used software WinDOAS.

The next error taken into consideration is a statistical Monte Carlo error from the used model McArtim. However, this error is rather small and can be neglected compared to the first mentioned error.

At last, there are errors due to uncertainties in the model assumptions, as for e.g. the aerosol profile and the appraisal of the height. These errors could not be determined quantitatively, and will therefore only be qualitatively discussed herein.

For the presented mean data, the mean standard deviation error was calulated from the measurement errors of each data point. No Gauss error propagation was applied, as the measurement error may be systematic and not statistically distributed. 


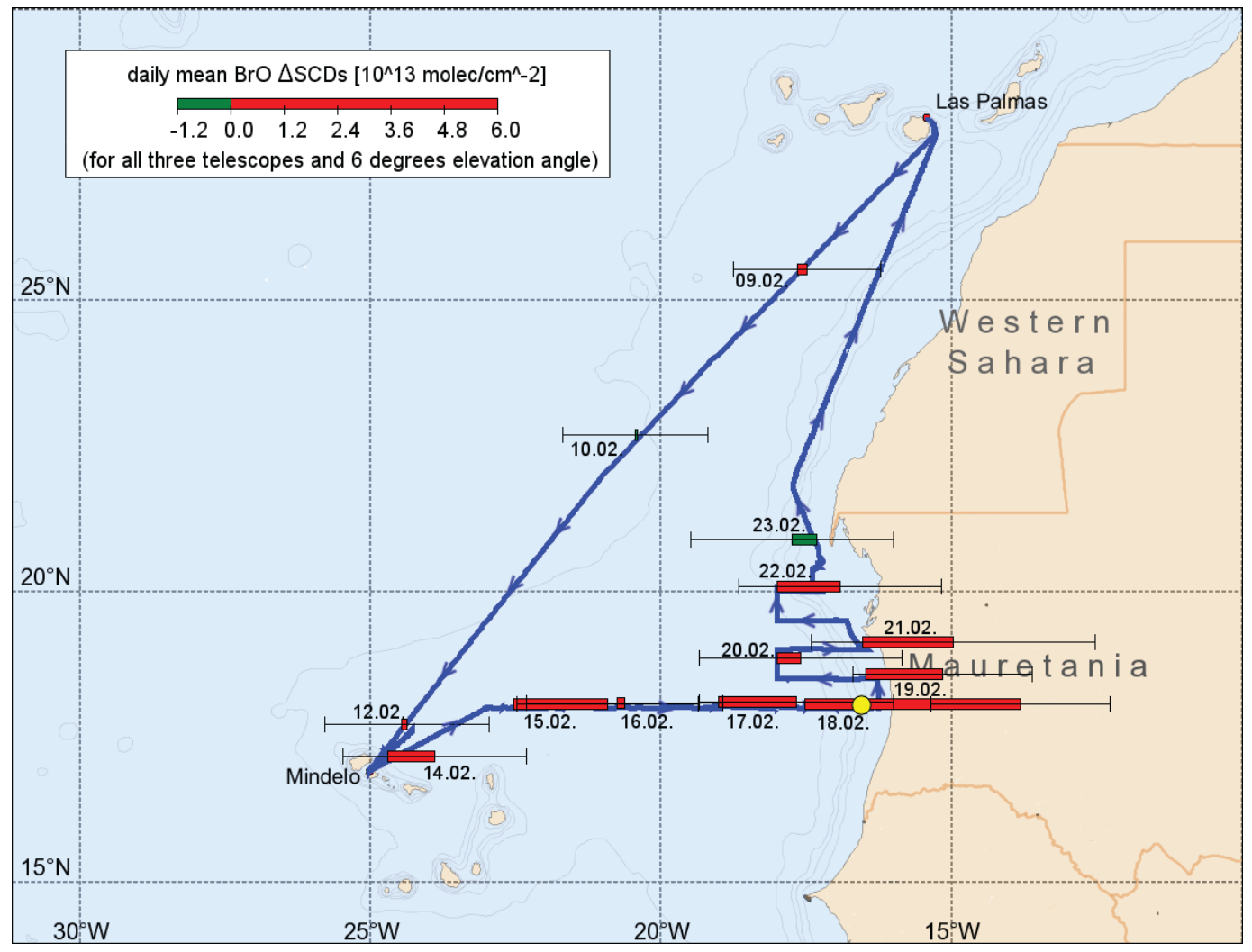

Fig. 2. The daily mean $\triangle \mathrm{SCD}$ values of $\mathrm{BrO}$ of all three telescopes, taken at $6^{\circ}$ elevation angles for the whole cruise (Posidon, $\mathrm{P} 348$, 8 February to 24 February 2007) are indicated by red bars, thin lines indicate the mean standard deviations (error of one single data point, no gauss error propagation). The values increase, when the ship was cruising along the coast of Mauritania. The yellow circle indicates the location, where the tropospheric BrO peak on 18 February 2007 was measured. Each bar is plotted at the ship coordinates at 12:00 UTC of the respective day. The data point on 11 February is missing due to malfunctions of the instrument and on 13 February as the ship was in the harbor during this day.

\section{Results}

The summary of our results, the average over the daily mean $\mathrm{BrO} \triangle \mathrm{SCDs}$ recorded at $6^{\circ}$ elevation angle of all three telescopes is indicated by bars in the map of the cruise shown in Fig. 2. The $\triangle \mathrm{SCD}$ secorded during the large early morning and evening solar zenith angles (higher than $70^{\circ}$ ) were excluded from Fig. 2, as they possibly include stratospheric contributions. Daily mean $\mathrm{BrO} \triangle \mathrm{SCDs}$ frequently exceeded $10^{13} \mathrm{molec} / \mathrm{cm}^{2}$. It can be seen, that the mean BrO $\triangle$ SCDs were higher, when the ship was cruising along the Western Coast of Africa, close to the Mauritanian upwelling region.

The $6^{\circ}$ elevation angle values were chosen since the SCDs did not further increase at smaller elevation angles as can be seen in Fig. 3, where mean $\mathrm{BrO} \triangle \mathrm{SCD}$ values are plotted as a function of the respective elevation angles. The reason for this behaviour might be the relatively high aerosol extinction close to the (water) surface, since the radiation is scattered very frequently there, and thus smaller (here smaller than $6^{\circ}$ ) elevation angles will not experience longer light paths anymore.
The $\mathrm{BrO}$ dSCD diurnal profiles (i.e. evaluations relative to a single noontime reference spectrum) showed the same characteristic "bath tube-shape" each day (see Fig. 4). This well known, characteristic shape is caused by the longer light path through the stratosphere in the morning and in the evening due to the higher solar zenith angles. Three sample days are shown in Fig. 4.

The highest tropospheric BrO slant column densities were detected on 18 February 2007 between 14:00 UTC and 16:00 UTC, as it is marked by an arrow in Fig. 4 and also marked with a yellow dot in Fig. 2. At this time, the ship was cruising in easterly direction, close to the Mauritanian upwelling region, at the geographical coordinates $18.0^{\circ} \mathrm{N}$ and $17.4^{\circ} \mathrm{W}$ to $18.0^{\circ} \mathrm{N}$ and $17.0^{\circ} \mathrm{W}$. 18 February 2007 was a clear and sunny day with the wind blowing from easterly direction, thus coming from the Mauritanian mainland.

Boundary layer BrO concentrations were calculated for this peak using the backward Monte Carlo radiative transfer model McArtim (Deutschmann, 2008). The dSCDs of $\mathrm{O}_{4}$ and BrO from 14:00 UTC until 16:00 UTC were used as input. 


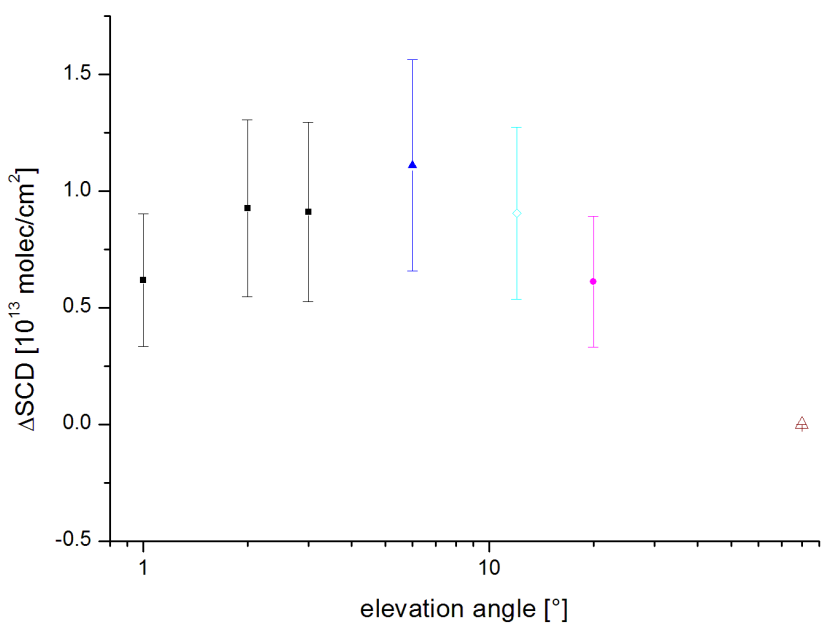

Fig. 3. Plot of the BrO $\triangle \mathrm{SCD}$ values with mean standard deviations (averaged from 14:00 UTC to 16:00 UTC) on 18 February as function of the MAX-DOAS elevation angles (on a logarithmic scale). The values do not rise anymore for angles smaller than $6^{\circ}$. (The value for the $80^{\circ}$ angle is zero, as this spectra was used as reference spectra.)

For the aerosol profile retrieval, at first, a run without any aerosols was performed. However, this led to too high air mass factors for the smaller elevation angles. Thus, some box profiles with different heights and different exponentially decreasing profiles were tested.

The best fit of the simulation of the $\mathrm{O}_{4}$ dSCDs was received using an exponentially decreasing aerosol profile with a scale height of $350 \mathrm{~m}$ and an extinction coefficient of $0.2 \mathrm{~km}^{-1}$ at the ground. The calculated as well as some of the modelled profiles can be seen in Fig. 5.

On the left panel of Fig. 4 one can see, that not only the $6^{\circ} \mathrm{dSCD}$ values, but also the dSCDs of $12^{\circ}$ and $20^{\circ}$ are significantly enhanced during the peak on 18 February, with the typical decrease of dSCD value with increasing elevation angle. This indicates that the height of the $\mathrm{BrO}$ layer reached up to relatively large altitudes $(1-2 \mathrm{~km})$, so that under the viewing direction of $20^{\circ}$, which for geometrical reasons generally is not so sensitive for trace gas layers close to the ground, one still retrieves significant dSCD values. For lower layer heights one would expect a steeper decrease of the respective $\mathrm{BrO}$ dSCDs with increasing elevation angle.

The most probable results yielded a vertical layer, that was a box profile with an effective height of $1 \mathrm{~km}$. However, the different yielded VCDs when assuming a box profile or an exponential decreasing profile were rather small. Alterations of the layer height of $\pm 0.1 \mathrm{~km}$ caused changes in the dSCD values below $5 \%$. The value of the vertical column density, in accordance with this profile and the measured dSCD values, was determined as $(3.6 \pm 1.3) \times 10^{13}$ molec cm$^{-2}$. This corresponds to a $\mathrm{BrO}$ mixing ratio of $10.2 \pm 3.7 \mathrm{ppt}$ for the $1 \mathrm{~km}$ thick layer. However, it was not possible to determine the layer height unambiguously with the available information on meteorological conditions. Supposing a layer height of $2 \mathrm{~km}$, the mixing ratio would still have been $5.1 \pm 1.8 \mathrm{ppt}$. Under extreme (and mostly unlikely) assumptions, with a layer height of $10 \mathrm{~km}$, the measured BrO SCDs would be consistent with a mixing ratio of $3.0 \pm 1.1 \mathrm{ppt}$. Nevertheless, the dSCDs during the peak event (as can be seen in Fig. 4) as well as the modelled AMFs were higher for smaller elevation angles, which are very strong indications for a tropospheric trace gas layer (see e.g. Wagner et al., 2007).

\section{Discussion}

Two remarkable results were found during this cruise. The first was the overall rise in the $\mathrm{BrO}$ slant column densities when travelling close to the African coast and the other the BrO peak seen on 18 February 2007.

The overall enhanced $\mathrm{BrO}$ levels can be caused by several reasons, which will be discussed in the following.

A very likely one is the proximity to the Mauritania upwelling region (e.g. Hagen, 2001), where higher concentrations of halogen precursors are expected due to the high biological activity.

It can be seen from Fig. 2, that the mean $\triangle$ SCDs of the 9, 10 and 23 February 2007 are very low. At these days the ship was the furthest north during the cruise and thus furthest away from the upwelling region (see Fig. 2). All days which show higher values are located further south. As the event measured on 18 February occurred during a very short time span (low homogeneous mixing), we concluded, that it cannot come from a constant extended source and has to be rather close. When considering, that the wind was mainly blowing from a north-eastern direction, this $\mathrm{BrO}$ enhancement can then very likely be explained by contributions from the upwelling region plus bromine emissions originating from the African mainland and being blown out to the ocean. The higher BrO levels close to the coast could thus be caused by the ship being located closer to the sources.

It is also worth mentioning that elevated $\mathrm{BrO}$ SCDs were already measured in the same region before, by Leser et al. (2003) and by Ibrahim (personal communication, 2008). Thus, these results can be seen as indication, that in this region higher $\mathrm{BrO}$ concentrations can arise.

Dust in the atmosphere might as well, as described in more detail in the introduction, in principle increase the levels of reactive halogen compounds in the atmosphere. Very high dust contents were found by Baker (personal communication, 2008) in air mass samples taken during this cruise. However, when comparing the time series of the dust levels evaluated by Baker and the BrO SCD values, no direct correlation (high dust and $\mathrm{BrO}$ values at the same time or high dust values followed by high $\mathrm{BrO}$ values) could be found between them. Therefore, it is not likely that aerosols were a major reason for the detected enhanced $\mathrm{BrO}$ values. 


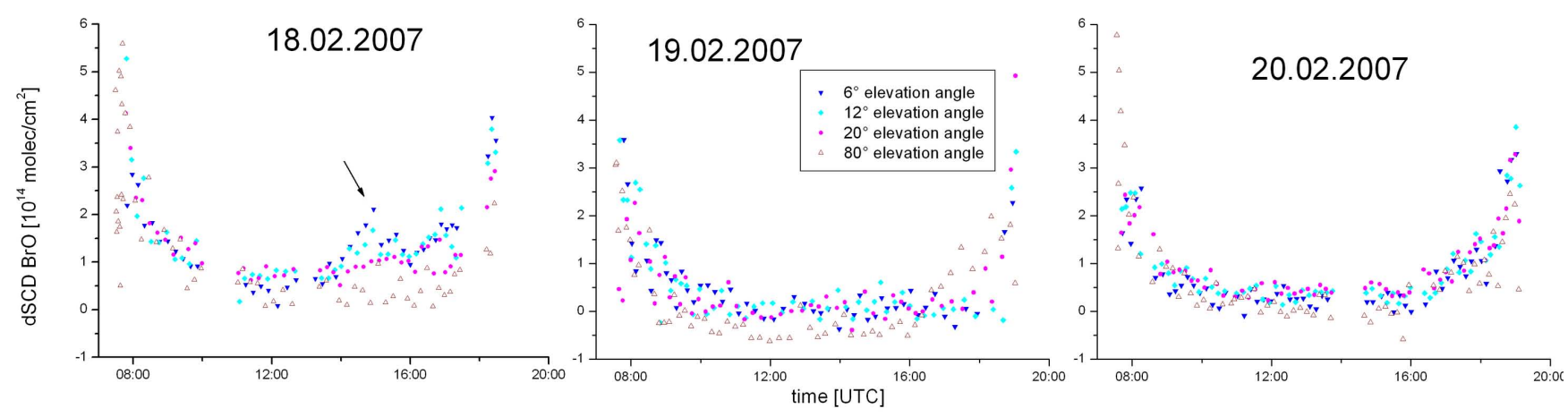

Fig. 4. The diurnal variation in the dSCDs of BrO on 18 to 20 February. The peak in the afternoon of 18 February (arrow) can be seen at the elevation angles $6^{\circ}$ (the largest enhancement), $12^{\circ}$ and $20^{\circ}$. It indicates tropospheric $\mathrm{BrO}$.

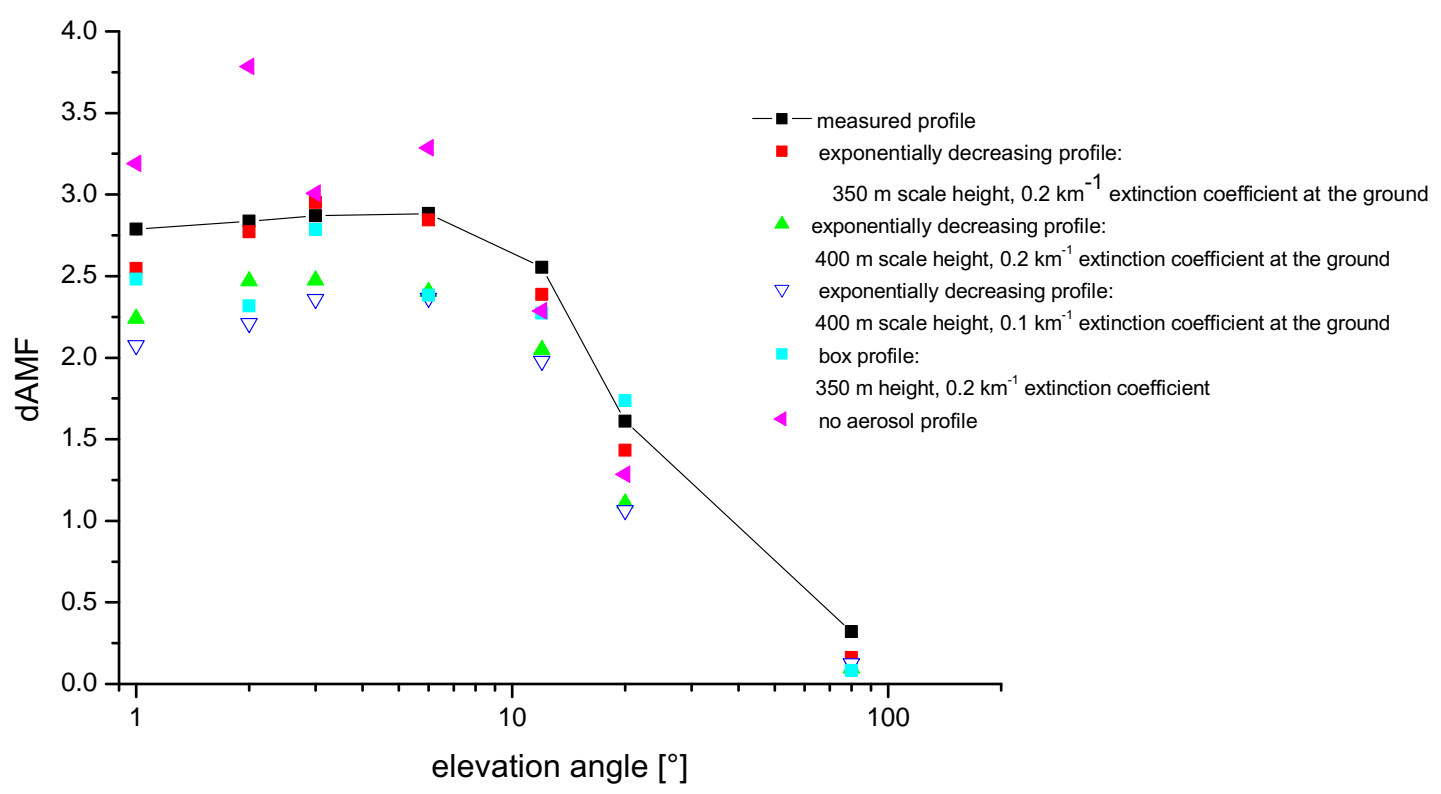

Fig. 5. The different elevation angles are plotted on a logarithmic scale versus the dAMFs for the measured (black line) and some modelled aerosol profiles. The exponentially decreasing aerosol profile with a scale height of $350 \mathrm{~m}$ and an extinction coefficient of $0.2 \mathrm{~km}^{-1}(\mathrm{red}$ dots in the graph) was used as fixed input further on. It can be seen, that it represents the measured dAMFs quite well, especially for the smaller elevation angles.

Halogen species coming from the Mauritanian salt lakes and from coastal mangrove trees can also be blown out to the open ocean, which might be another source for the measured enhancement. During the days where the ship was cruising along the African coast, the wind was mainly blowing from north-eastern direction. Thus, it came from the mainland, indicating that halogen species from there might have contributed to the measured high values. However, no direct correlation between the direction of the wind and the measured $\mathrm{BrO}$ values could be found.

During the $\mathrm{BrO}$ peak event observed on 18 February 2007 even the SCDs at a $20^{\circ}$ elevation angle were significantly enhanced. This indicates elevated BrO levels up to several $\mathrm{km}$ altitude and thus, that the measured $\mathrm{BrO}$ might have travelled already some time in the surveyed air masses, where it could have had time to disperse vertically before reaching the ship. The source of the $\mathrm{BrO}$ peak might therefore be due to halogenated hydrocarbons emitted by tropical halophytes growing in Mauritania. Also organohalogens, emitted from algae close to the coast, might have contributed to the $\mathrm{BrO}$ peak event.

$48 \mathrm{~h}$ back trajectory calculations, which were done using HYSPLIT (Draxler and Rolph, 2003; Rolph, 2003), also displayed that the wind was coming most of the time from north-east. The trajectories from 17 to 22 February 2007, in each case at 15:00 UTC, are shown in Fig. 6. They show that on days with high mean $\mathrm{BrO}$ concentration (e.g. on 18 February), the air mass was pasing over Mauretania and then 

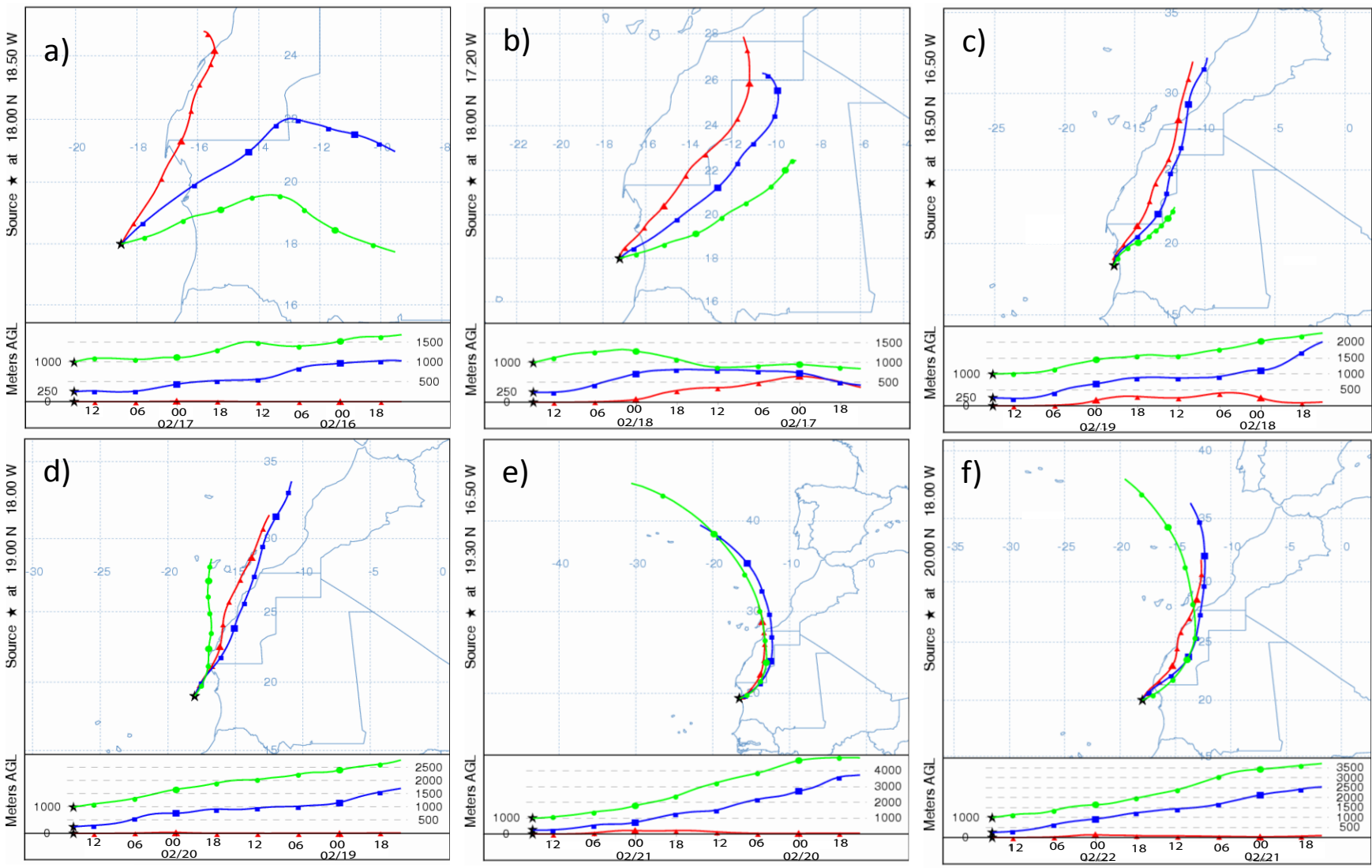

Fig. 6. The results of the $48 \mathrm{~h}$ back trajectory calculations done with HYSPLIT for (a) 17 February, (b) 18 February, (c) 19 February, (d) 20 February, (e) 21 Februray and (f) 22 February. Each trajectory arrives at 15:00 UTC of the particular day at the present ship position. The BrO dSCDs were highest on 18 February, and on 17, 19, 21 February still high, but less enhanced. The values were smaller on 22 February and smallest on the 20th.

over the upwelling region in front of the Mauretanian coast before reaching the ship. On days with lower concentrations, like on 20 February, the wind was coming from a more northerly direction. However, the trend for days with lower values is less clear as in these cases already slight errors in the Hysplit calculations might lead to misinterpretations, depending if the wind passed over land or not. Furthermore, the trajectories present only one point in time and do not need to be representative for the whole day. From these results can be concluded, that the $\mathrm{BrO}$ source region is either bordered to the north, when the wind is not passing over the upwelling region or that it is located in Mauretania.

\section{Conclusions}

Very high $\mathrm{BrO}$ mixing ratios ( $>10 \mathrm{ppt})$ could be measured in the lower troposphere over the Eastern North-Atlantic with the MultiAXis-Differential Optical Absorption Spectroscopy. The data were collected during February 2007 during a ship cruise on the research vessel Poseidon, as a part of the Surface Ocean PRocesses in the ANthropocene
(SOPRAN) project. The peak $\mathrm{BrO}$ concentration was estimated, using radiative transfer models yielding a layer height of $1 \mathrm{~km}$, to $(10.2 \pm 3.7) \mathrm{ppt}$. This is the most probable scenario, but the layer height could not be determined unambiguously. A higher layer would lead to somewhat smaller, but still remarkable $\mathrm{BrO}$ values, in particular keeping in mind that these elevated levels would prevail in a large fraction of the tropospheric column.

Furthermore, the overall concentrations increased when the ship was cruising close to the African Coast suggesting the upwelling region and the African mainland as a source of reactive bromine (or its precursors). No direct correlation between the $\mathrm{BrO}$ data and dust or wind data, also collected during the cruise, could be found. Thus, the measured elevated $\mathrm{BrO}$ values are probably caused by algae from the upwelling region close to the African coast or by mangroves growing at Mauritania, as the wind was most of the time blowing from the African mainland.

The concentration of IO, which was also measured using the MAX-DOAS technique, never exceeded the detection limit, which was estimated to $(0.77 \pm 0.55)$ ppt. 
Acknowledgements. The authors would like to thank A. Baker for the appropriation of his data. Furthermore the scientists, especially $\mathrm{H}$. W. Bange, on board the research vessel Poseidon during cruise P348 for their help and support during and after the cruise as well as the captain and the crew of the ship.

Cruise P348 was part of the joint project SOPRAN and was funded by the Bundesministerium für Bildung und Forschung (BMBF) through grants $03 \mathrm{~F} 0462 \mathrm{~A}$ and $03 \mathrm{FO} 462 \mathrm{~F}$.

The authors gratefully also acknowledge the NOAA Air Resources Laboratory (ARL) for the provision of the HYSPLIT transport and dispersion model and READY website (http://www.arl.noaa.gov/ready.html) used in this publication.

Edited by: M. van Roozendael

\section{References}

Barrie, L., Bottenheim, J., Schnell, R., Crutzen, P., and Rasmussen, R.: Ozone destruction and photochemical reactions at polar sunrise in the lower Arctic atmosphere, Nature, 334, 138-141, 1988.

Bogumil, K., Orphal, J., Homann, T., Voigt, S., Spietz, P., Fleischmann, O., Vogel, A., Hartmann, M., Bovensmann, H., Frerick, J., and Burrows, J.: Measurements of molecular absorption spectra with the SCIAMACHY pre-flight model: Instrument characterization and reference data for atmospheric remote sensing in the 230-2380 nm region, J. Photochem. Photobiol. A. Chem., 157, 167-184, 2003.

Bottenheim, J. W., Barrie, L. A., Atlas, E., Heidt, L. E., Niki, H., Rasmussen, R. A., and Shepson, P. B.: Depletion of lower tropospheric ozone during Arctic spring: The polar sunrise experiment 1988, J. Geophys. Res., 95, 18555-18568, 1990.

Carpenter, L. J., Jones, C. E., Dunk, R. M., Hornsby, K. E., and Woeltjen, J.: Air-sea fluxes of biogenic bromine from the tropical and North Atlantic Ocean, Atmos. Chem. Phys., 9, 1805-1816, 2009 ,

http://www.atmos-chem-phys.net/9/1805/2009/.

Deutschmann, T.: Atmospheric Radiative Transfer Modelling with Monte Carlo Methods, Diploma thesis, Institut für Umweltphysik, Universität Heidelberg, Germany, 2008.

Draxler, R. and Rolph, G.: HYSPLIT (HYbrid Single-Particle Lagrangian Integrated Trajectory) Model access via NOAA ARL READY Website (http://www.arl.noaa.gov/ready/hysplit4.html), NOAA Air Resources Laboratory, Silver Spring, MD, 2003.

Fan, S. and Jacob, D.: Surface ozone depletion in Arctic spring sustained by bromine reactions on aerosols, Nature, 359, 522524, 1992.

Grainger, J. and Ring, J.: Anomalous Fraunhofer line profiles, Nature, 193, p. 762, 1962.

Hagen, E.: Northwest African upwelling scenario, Oceanol. Acta, 24, 113-128, 2001.

Hönninger, G. and Platt, U.: Observations of BrO and its vertical distribution during surface ozone depletion at Alert, Atmos. Environ., 36, 2481-2489, 2002.

Hönninger, G., von Friedeburg, C., and Platt, U.: Multi axis differential optical absorption spectroscopy (MAX-DOAS), Atmos. Chem. Phys., 4, 231-254, 2004, http://www.atmos-chem-phys.net/4/231/2004/.
Kraus, S.: DOASIS - A Framework Design for DOAS, Ph.D. thesis, Combined Faculties for Mathematics and for Computer Science, University of Mannheim, Germany, 2005.

Leser, H., Hönninger, G., and Platt, U.: MAX-DOAS measurements of $\mathrm{BrO}$ and $\mathrm{NO}_{2}$ in the marine boundary layer., Geophys. Res. Lett., 30(10), 1537, doi:10.1029/2002GL015811, 2003.

Middleton, N. J. and Goudie, A. S.: Saharan Dust: Sources and Trajectories, Trans. Inst. Br. Geogr., 26, 165-181, 2001.

Molina, L. T. and Rowland, F. S.: Stratospheric sink for chlorofluromethanes: chlorine atom catalyzed destruction of ozone, Nature, 249, 820-822, 1974.

Platt, U.: Differential optical absorption spectroscopy (DOAS), in: Air Monitoring by Spectroscopic Techniques, edited by: Sigrist, W. M., 127, 27-84, John Wiley \& Sons, Inc., 1994.

Platt, U. and Lehrer, E.: Arctic Tropospheric Ozone Chemistry, ARCTOC, Final Report of the EU-Project No. EV5V-CT930318, Heidelberg, 1996.

Quack, B., Atlas, E., Petrick, G., Stroud, V., Schauffler, S., and Wallace, D.: Oceanic bromoform sources for atmosphere, Geophys. Res. Lett., 31, L23S05, doi:10.1029/2004GL020597, 2004.

Read, K. A., Mahajan, A. S., Carpenter, L. J., Evans, M. J., Faria, B. V. E., Heard, D. E., Hopkins, J. R., Lee, J. D., Moller, S. J., Lewis, A. C., Mendes, L., McQuaid, J. B., Oetjen, H., SaizLopez, A., Pilling, M. J., and Plane, J. M. C.: Extensive halogenmediated ozone destruction over the tropical atlantic ocean, Nature, 453, 1232-1235, 2008.

Rhew, R. C., Miller, B. J., and Weiss, R. F.: Natural methyl bromide and methyl chloride emissions from coastal salt marshes, Nature, 402, 292-295, 2000.

Rolph, G.: Real-time Environmental Applications and Display sYstem (READY) Website (http://www.arl.noaa.gov/ready/hysplit4. html), NOAA Air Resources Laboratory, Silver Spring, MD, 2003.

Saiz-Lopez, A., Plane, J., and Shillito, J.: Bromine oxide in the midlatitude marine boundary layer, Geophys. Res. Lett., 31, L03111, doi:10.1029/2003GL018956, 2004.

Simpson, W. R., von Glasow, R., Riedel, K., Anderson, P., Ariya, P., Bottenheim, J., Burrows, J., Carpenter, L. J., Frieß, U., Goodsite, M. E., Heard, D., Hutterli, M., Jacobi, H.-W., Kaleschke, L., Neff, B., Plane, J., Platt, U., Richter, A., Roscoe, H., Sander, R., Shepson, P., Sodeau, J., Steffen, A., Wagner, T., and Wolff, E.: Halogens and their role in polar boundary-layer ozone depletion, Atmos. Chem. Phys., 7, 4375-4418, 2007, http://www.atmos-chem-phys.net/7/4375/2007/.

Sinreich, R., Frieß, U., Wagner, T., and Platt, U.: Multi axis differential optical absorption spectroscopy (MAX-DOAS) of gas and aerosol distributions, Faraday Discuss., 130, 153-164, 2005.

Stutz, J. and Platt, U.: Numerical Analysis and Estimation of the Statistical Error of Differential Optical Absorption Spectroscopy Measurements with Least-Squares methods, Appl. Optics, 35, 6041-6053, 1996.

Tuckermann, M., Ackermann, R., Gölz, C., Lorenzen-Schmidt, H., Senne, T., Stutz, J., Trost, B., Unold, W., and Platt, U.: DOAS-observation of Halogen Radical-catalysed Arctic Boundary Layer Ozone Destruction during the ARCTOC-campaigns 1995 and 1996 in Ny-Alesund, Spitsbergen, Tellus, 49B, 533$555,1997$.

Usher, C. R., Michel, A. E., and Grassian, V. H.: Reactions on Mineral Dust, Chem. Rev., 103, 4883-4939, 2003. 
Vandaele, A. C., Hermans, C., Simon, P. C., Carleer, M., Colin, R., Fally, S., Mérienne, M., Jenouvrier, A., and Coquart, B.: Measurements of the NO2 absorption cross-section from $42000 \mathrm{~cm}^{-1}$ to $10000 \mathrm{~cm}^{-1}(238-1000 \mathrm{~nm})$ at $220 \mathrm{~K}$ and 294 K, J. Quant. Spectrosc. R. Transf., 59, 171-184, 1998.

van Roozendael, M. and Fayt, C.: WinDOAS 2.1. Software User Manuel, 2001.

Varner, R. K., Crill, P. M., and Talbott, R. W.: Wetlands: a potentially significant source of atmospheric methylbromide and methylchloride, Geophys. Res. Lett., 26, 2433-2436, 1999.

Vogt, R., Crutzen, P. J., and Sander, R.: A mechanism for halogen release from sea-salt aerosol in the remote marine boundary layer, Nature, 383, 327-330, 1996.

von Glasow, R. and Crutzen, P. J.: Tropospheric Halogen Chemistry, edited by: Holland, H. D. and Turekian, K. K., Treatise on Geochemistry Update1, 4.02, 1-67, 2007.

Wagner, T., Dix, B., von Friedeburg, C., Frieß, U., Sanghavi, S., Sinreich, R., and Platt, U.: MAX-DOAS O4 measurements: a new technique to derive information on atmospheric aerosols - Principles and information content, J. Geophys. Res., 109, D22205, doi:10.1029/2004JD004904, 2004.
Wagner, T., Ibrahim, O., Sinreich, R., Frieß, U., von Glasow, R., and Platt, U.: Enhanced tropospheric BrO over Antarctic sea ice in mid winter observed by MAX-DOAS on board the research vessel Polarstern, Atmos. Chem. Phys., 7, 3129-3142, 2007, http://www.atmos-chem-phys.net/7/3129/2007/.

Wennberg, P.: Bromine explosion, Nature, 397, 299-300, 1999.

Wilmouth, D. M., Hanisco, T. F., Donahue, N. M., and Anderson, J. G.: Fourier transform ultraviolet spectroscopy of the $A^{2} \Pi_{3 / 2} \leftarrow X^{2} \Pi_{3 / 2}$ transition of BrO, J. Phys. Chem., 103, 8935-8945, 1999.

Williams, J., Gros, V., Atlas, E., Maciejczyk, K., Batsaikhan, A., Yassa, N., Sander, R., and Dingenen, R. V.: Possible evidence for a connection between methyl iodide emissions and Saharan dust, J. Geophys. Res., 112, D07302, doi:10.1029/2005JD006702, 2007. 